\title{
INTENTION TO ADOPT ISLAMIC QUALITY STANDARD: A STUDY OF HOTELS IN PENINSULAR MALAYSIA
}

\author{
Rozila Ahmad* \\ Noor Azimin Zainol \\ Mohd Hyrul Abu Karim \\ School of Tourism, Hospitality and Event Management, UUM College of Law, \\ Government and International Studies, Universiti Utara Malaysia, 06010 UUM Sintok, \\ Kedah Darul Aman, Malaysia.
}

\begin{abstract}
Since 2010, Malaysia has been among the first choice for travel destination in the global Muslim travel market. To better serve the market, in 2013 Islamic Quality Standard for hotels (IQS) was introduced in Malaysia. However, many are skeptical about its feasibility. It is not clear whether hotels in Malaysia are keen to adopt this standard. Despite the ambiguity, a quantitative study to ascertain the intention to adopt IQS remains scarce. The purpose of this study is to investigate hotel manager's intention to adopt IQS. A total of 355 questionnaires were distributed to hotel managers throughout Peninsular Malaysia. Based on 72 usable returned questionnaires, it was found that most of the hotel managers were undecided on whether to adopt IQS or not. The percentage of those who were positive about the intention to adopt IQS was only slightly higher than those who were negative about it. Comparison between Muslim and non-Muslim intention in adoption shows a small but significant difference between the two groups. This paper contributes to the literature on Shariah-compliant, and it is relevant to civilization as it provides knowledge that may enhance understanding and cooperation among the stakeholders which is crucial for social harmony.
\end{abstract}

\footnotetext{
*Corresponding author: rozila@uum.edu.my eISSN 2636-9265 (C) Centre for Civilisational Dialogue DOI: https://doi.org/10.22452/KATHA.vol15no1.2
} 
Keywords: Intention to adopt, Islamic Quality Standard, Shariahcompliant, Hotel, Malaysia.

\section{Introduction}

Current global tourism industry recognizes the significance of Islamic tourism and hospitality. Based on Thomson Reuters (2018), Muslim expenditure across lifestyle sector represents almost 12 percent in 2017, and by 2022 it is predicted that Muslim market will reach USD 3.081 trillion. There is optimism that Muslim market and expenditure will expand steadily, and this will benefit countries that promote Islamic Tourism (Pew Research Centre, 2011). Malaysia has retained its position as the first choice for travel destination in global Muslim travel market for eight consecutive years, followed closely by Indonesia and United Arab Emirates (Mastercard\& CrescentRating, 2018). To meet the basic needs of Muslim tourists, the Ministry of Tourism, Arts and Culture Malaysia has introduced the Muslim-friendly hotel. Muslim-friendly hotel refers to hotels that provide basic facilities to satisfy the Muslim tourist needs (Samori\&Rahman, 2013). Another term which is closely related to Muslim friendly hotel is Shariah-compliant hotel. Shariahcompliant hotel is also known as Islamic hotel (Razalli, Abdullah\&Hassan, 2012).

Despite having the opportunity to generate revenue from the global Muslim travel market, Ahmat, Ridzuan, Din, Zainol \& Razali (2015) found that the development of Islamic hotels in Malaysia is quite slow due to the lack of consensus among hotel operators, and no standard guideline or procedure has been introduced by the Malaysian Islamic authorities. Therefore, Universal Crescent Standard Centre (UCSC) has developed the Islamic Quality Standard for hotels (IQS). UCSC is an organization headquartered in Shah Alam, Malaysia which was formed to develop a standard of Islamic quality for hotels. The standard measures the level of compliance to the Shariah or Islamic principles all over the world (Othman, 2013).IQS serves as a guideline for hotels that intend to 
become Muslim-friendly or Shariah-compliant, and adopt the Islamic hotel concept.

IQS is an alternative to Star Rating standard (Channel Muslim Media News, 2013). Examples of hotels in Malaysia that have adopted IQS are De Palma Hotels, The Grand Blue Wave Hotel, Shah Alam and the Caprice Group of Hotels in Turkey (Othman, 2013). The number of hotels that has adopted IQS in Malaysia is very small compared to Star Rating, Salam Standard and CrescentRating. It is not clear whether many hotels in Malaysia intend to adopt IQS. Hence, this study seeks to investigate the intention of hotels in Malaysia to adopt IQS in their respective organizations. Many of the top management and owners of hotels in Malaysia are non-Muslim especially four and five-star hotels that are either owned or franchised by Multi-National Companies based in foreign countries such as Singapore, United Kingdom and United States of America (Malaysian Association of Hotel Owners, 2019; Samori,2013). Thus, this study seeks to answer the following research questions.

1. Do hotel operators in Malaysia intend to adopt IQS?

2. Is there any difference in the intention to adopt IQS among the Muslim and non-Muslim hotel operators?

\section{Literature Review}

With the intention to become a useful guide for hotel owners who wish to become Muslim-friendly hotel, the formulation of IQS integrates the importance of the quality of physical facilities and the quality of customer services conforming to Islamic principles (Othman, 2013). According to Othman (2013), Star Rating and Diamond Rating are not Muslim-friendly because they provide alcoholic beverages in their hotel rooms which contributes to their rating, and is against the Islamic principles. Besides IQS, there are other assessment tools that can serve as a guide to Muslim-friendly hotels such as CrescentRating, Salam Standard and Shariah Islamic Hotel Assessment Tool (SIHAT). IQS, CrescentRating and Salam Standard begin their rating on a scale of 1 to a higher rating that requires the achievement of the lower rating. 


\section{Islamic Quality Standard}

IQS was launched in 2013 (Channel Muslim Media News, 2013). It has seven levels of classifications ranging from IQS1 to IQS7 (Othman, 2013). In order to achieve the higher levels, the requirements of the lower levels must be fulfilled first. Table 1 lists some of the distinctive requirements for IQS certification which makes it different from Star Rating standard. Different from other assessment tools, to attain IQS5, the hotel must have spacious bedroom for guests to perform prayer. In addition, the hotel must also appoint a full time imam (Othman \& Othman, 2013). The higher the IQS level, the more difficult and costly it is for hotels to comply. The attainment of IQS6 requires more facilities to separate male, female and guests with family, and IQS7 requires more than four prayer rooms with imam appointed and more than two luxurious halal restaurants (Othman\& Othman, 2013). In summary, it is easier to attain the highest standard for Star Rating compared to IQS.

Table 1

Distinctive Requirements for IQS Certification

\begin{tabular}{lc}
\hline \multicolumn{1}{c}{ Distinctive Requirement } & Level \\
\hline - Sign of Qiblat(direction of Makkah), prayer mat and & 1 \\
prayer time schedule. \\
-Serving halal continental breakfast for Muslim \\
guests. \\
- At least 2 prayer rooms for Muslim staff and guests. \\
\hline - A dining room/restaurant serving halal food. \\
\hline - Halal restaurant with room service for guests. \\
\hline $\begin{array}{l}\text { - Swimming pool or spa facilities (for guests) with } \\
\text { different time scheduled for male and female. }\end{array}$ \\
\hline - Spacious bedroom for guests to perform their \\
prayer. \\
- Prayer room available for guests with full time imam \\
appointed.
\end{tabular}


- Separate swimming pools, spa and gymnasium for 6 male and female.

- Restaurants provide special sitting area for female guest and guest with family.

- A choice of special lounge for female and guest with family in public areas.

- Additional facilities: separate saloon, boutique, arcade, etc. for male and female.

- Additional services: during Ramadhan, hotel serves Sahur and Iftar for Muslim guests.

- More than two separate swimming pools and spa 7 centres for male and female.

- Separate meeting and business centres for male and female.

- More than four prayer rooms with Imam appointed.

- More than two luxurious halal restaurants that serve different halal international cuisines.

Source: [Othman and Othman (2013)]

\section{CrescentRating}

CrescentRating, a private company with its headquarters in Central Singapore was founded in 2008 by Fazal Bahardeen (Owler, 2019). CrescentRating claims to be the world's leading authority in halal travel. The criteria used by CrescentRating for halal rating are: the extent of halal food availability, prayer facilities, halal food availability during Ramadhan, and the level of non-halal activities in the hotel (CrescentRating, 2019). Hotels can attain top score for all the criteria when they do the following: comply to "only halal food" regulation on entire premises, provide all the required facilities for Muslim guests to pray, provide meals for Sahur and Iftaar, and provide transportation to local mosque during Ramadhan, and equipped with separate spa, pool and gym for women (CrescentRating, 2019). Similar to IQS, CrescentRating rates on a scale of one Crescent to seven Crescent. However, the attainment of seven Crescent is easier with CrescentRating compared to IQS. With CrescentRating, many hotels can achieve three Crescent without any structural changes. Only few changes are 
needed to achieve five Crescent, and hotels that achieve six and seven Crescent are those which are specialize in catering to the Muslim needs. Hotels with six and seven Crescent only serve halal food and beverages, and they also provide other family friendly facilities (CrescentRating, 2019). Table 2 provides an overview of CrescentRating standard.

Table 2

CrescentRating Standards Overview

\begin{tabular}{l}
\hline Requirement \\
\hline - Hotels are helpful to Muslim travelers. They will be \\
able to provide information regarding prayer time, \\
prayer direction, nearby mosques and halal food. \\
These hotels may not provide halal food in the hotel \\
premise.
\end{tabular}

- Hotels are helpful to Muslim travelers. They will be 4 able to provide information regarding prayer time, prayer direction, nearby mosques and halal food.

-The hotels may provide some level of halal food service. They can either have halal breakfast or room service or they may claim that all food in the hotel is halal but not independently verified by a halal food certification authority.

-Hotels are helpful to Muslim travelers. They will be 5 able to provide information regarding prayer time, prayer direction, nearby mosques and halal food.

-The hotels will have a halal certified kitchen or restaurant.

-Hotels are helpful to Muslim travelers. They will be 6-7 able to provide information regarding prayer time, prayer direction, nearby mosques and halal food.

-The hotels take into account most of the needs of a halal conscious traveler in their services and facilities. They will be serving only halal food and beverages apart from having other family friendly facilities.

Source: [CrescentRating website (2019)] 


\section{Salam Standard}

Salam Standard is an online hotel reference tool dedicated to Muslim travelers. It was launched in 2015 (British Muslim Magazine, 2015). Salam Standard was developed based on a survey on 50,000 Muslim travelers to identify the important services and amenities that they need when traveling. In 2017 more than 55,000 hotels were already indexed and displayed their Muslim-friendly services and amenities (Travel Weekly Asia, 2017). The ratings used by Salam Standard are Bronze, Silver, Gold and Platinum. Hotels are rated based on their provision of Muslim facilities and halal food. Hotels that provide basic Muslim facilities are certified with Bronze, Silver for provision of medium Muslim facilities, Gold for accommodation with extensive Muslim facilities and Platinum for accommodation with outstanding Muslim facilities. The criteria for Salam Standard certification are listed in Table 3. The attainment of the highest standard is easier with Salam Standard compared to other three assessment tools including IQS.

Table 3

Salam Standard Certification Criteria

\begin{tabular}{lc}
\hline \multicolumn{1}{c}{ Criteria } & Level \\
\hline$-100 \%$ of the rooms with shower/toilet or bath & Bronze \\
tub/toilet & \\
-A Muslim Praying Mat is available or can be & \\
requested & \\
-Qiblat is available or can be requested & \\
\hline
\end{tabular}


-Fulfils the requirement for Bronze

Silver

-A list of halal restaurants nearby the hotel is available in the room (or can be requested to be made available)

-There is no alcohol in the mini-bar of the hotel

(or it can be requested to be removed before arrival of guest)

- Fulfils the requirement for Silver

Gold

-The hotel offers halal certified food (breakfast

and/or room service) certified by a locally

recognized certification body (e.g. in Malaysia certified by JAKIM)

- Fulfils the requirement for Gold

Platinum

-The whole premise is alcohol-free

Source: [Salam Standard website (2019)]

\section{Shariah Islamic Hotel Assessment Tool (SIHAT)}

SIHAT, introduced by three academicians from Universiti Utara Malaysia, Mohd Rizal Razalli, Risyawati Mohamed Ismail and Noorulsadiqin Azbiya Yaacob in 2015can be used to evaluate hotel's compliance to Shariah principles (Razalli et al., 2015). Different from other assessment tools discussed, SIHAT has not yet been launched or commercialized. Noting that the hotel facilities should be comprehensively operated based on Shariah principles, SIHAT includes the assessment of human resource, marketing and the financial system of the hotel. Generated from an exploratory study of Shariah-compliant hotels in Malaysia, SIHAT has 64 attributes that are categorized into five main practices namely administration, common areas, bedroom, services and food and beverages (Razalli et al., 2015). SIHAT has the highest level of compliance to Islamic principles compared to IQS, Salam Standard and CrescentRating. SIHAT is more complex and difficult to apply especially when the hotel owners and managers are non-Muslim. A few of SIHAT items are listed in Table 4.

Table 4 
Examples of SIHAT items

\begin{tabular}{|c|c|c|c|c|c|c|}
\hline \multirow[t]{2}{*}{ No. } & \multirow[t]{2}{*}{$\begin{array}{l}\text { Hotel operations } \\
\text { practices }\end{array}$} & \multicolumn{2}{|c|}{$\begin{array}{c}\text { The } \\
\text { hotel } \\
\text { has: }\end{array}$} & \multicolumn{3}{|c|}{$\begin{array}{l}\text { Level of adoption } \\
\text { of each practise: }\end{array}$} \\
\hline & & \multicolumn{2}{|c|}{ Standard } & \multicolumn{3}{|c|}{ Advanced } \\
\hline 1 & $\begin{array}{l}\text { ADMINISTRATION } \\
\text { PRACTICES }\end{array}$ & No & Yes & Low & Med & High \\
\hline 1.1 & Management & & & & & \\
\hline 1.1 .1 & $\begin{array}{l}\text { Shariah advisory } \\
\text { committee }\end{array}$ & 0 & 1 & 1 & 2 & 3 \\
\hline 1.1 .2 & $\begin{array}{l}\text { Islamic quality principles } \\
\text { in hotel policy }\end{array}$ & 0 & 1 & 1 & 2 & 3 \\
\hline 1.1.3 & Internal audit & 0 & 1 & 1 & 2 & 3 \\
\hline 1.1 .4 & Improvement program & 0 & 1 & 1 & 2 & 3 \\
\hline 1.1 .5 & $\begin{array}{l}\text { Zakat / Social } \\
\text { responsibility payment }\end{array}$ & 0 & 1 & 1 & 2 & 3 \\
\hline 1.2 & Islamic Finance & & & & & \\
\hline 1.2 .1 & Salary payment & 0 & 1 & 1 & 2 & 3 \\
\hline 1.2 .2 & Income saving & 0 & 1 & 1 & 2 & 3 \\
\hline 1.2 .3 & Investment & 0 & 1 & 1 & 2 & 3 \\
\hline 1.3 & $\begin{array}{l}\text { Islamic Human } \\
\text { Resource }\end{array}$ & & & & & \\
\hline 1.3 .1 & $\begin{array}{l}30 \% \text { ratio of Muslim } \\
\text { staff }\end{array}$ & 0 & 1 & 1 & 2 & 3 \\
\hline 1.3 .2 & $\begin{array}{l}\text { Muslim dress code / } \\
\text { proper attire }\end{array}$ & 0 & 1 & 1 & 2 & 3 \\
\hline 1.3 .3 & $\begin{array}{l}\text { Prayer room and time for } \\
\text { staff }\end{array}$ & 0 & 1 & 1 & 2 & 3 \\
\hline 1.3 .4 & $\begin{array}{l}\text { Separate changing room } \\
\text { (men / women) for staff }\end{array}$ & 0 & 1 & 1 & 2 & 3 \\
\hline 1.3 .5 & $\begin{array}{l}\text { Muslim male staff break } \\
\text { for Friday prayer }\end{array}$ & 0 & 1 & 1 & 2 & 3 \\
\hline 1.3 .6 & Friendly and helpful staff & 0 & 1 & 1 & 2 & 3 \\
\hline 1.3 .7 & $\begin{array}{l}\text { Safety and security for } \\
\text { staff }\end{array}$ & 0 & 1 & 1 & 2 & 3 \\
\hline
\end{tabular}




\begin{tabular}{lllllll}
\hline 2 & $\begin{array}{l}\text { COMMON AREAS } \\
\text { PRACTICES }\end{array}$ \\
\hline 2.1 & $\begin{array}{l}\text { Separate facilities for } \\
\text { men and women / time } \\
\text { allocation }\end{array}$ & & & & & \\
\hline 2.1 .1 & Spa & 0 & 1 & 1 & 2 & 3 \\
\hline 2.1 .2 & Gym & 0 & 1 & 1 & 2 & 3 \\
\hline 2.1 .3 & Recreation / Sport & 0 & 1 & 1 & 2 & 3 \\
\hline 2.1 .4 & Swimming pool & 0 & 1 & 1 & 2 & 3 \\
\hline 2.1 .5 & Lounge & 0 & 1 & 1 & 2 & 3 \\
\hline 2.1 .6 & Lift & 0 & 1 & 1 & 2 & 3 \\
\hline Low $=<33 \% \quad$ Medium $=34-67 \%$ & & High $=68-100 \%$
\end{tabular}

Source: [Razalli et al. (2015)]

In comparison, CrescentRating is the earliest launched standard suitable with its claim "the world's leading authority on halal travel" (CrescentRating, 2019). Introduced in 2015, the launching of SIHAT remains unheard until today. This could be due to its complexity and high level of Shariah principles compliance. With SIHAT, operation and management aspects must also comply to Shariah principles, while others only focus on the provision of services and facilities (Razalli et al., 2015). In terms of Islamic Hotel branding, only IQS uses both terms, Muslim friendly and Shariahcompliant. CrescentRating and Salam Standard are clearly positioned as Muslim friendly. The rating used by IQS, CrescentRating and Salam Standard appears to have a commercial value. While "Crescent" is meant to symbolize Islam, "bronze, silver, gold and platinum" are the hierarchy of precious substance. Practicality is judged based on the ability to fulfill the standard's requirements considering the cost incurred to provide the facilities and services required, and the ability to attract customers and generate return on investment (Henderson, 2010; Samori, 2013). Popularity is reflected by the number of hotels that have adopted the assessment tool (or standard) and the ease to obtain information about the standard through communication media. To conclude, IQS universal practicality and popularity is lower than Salam Standard and CrescentRating. The comparison is summarized in Table 5. 
Table 5

Comparison of Assessment Tools

\begin{tabular}{lcccc}
\hline $\begin{array}{l}\text { Assessment } \\
\text { Tools }\end{array}$ & IQS & CrescentRating & $\begin{array}{c}\text { Salam } \\
\text { Standard }\end{array}$ & SIHAT \\
\hline $\begin{array}{l}\text { Date } \\
\text { Launched }\end{array}$ & 2013 & 2008 & 2015 & - \\
\hline $\begin{array}{l}\text { Islamic } \\
\text { Hotel } \\
\text { Branding }\end{array}$ & $\begin{array}{c}\text { Muslim } \\
\text { Friendly } \\
\text { and } \\
\text { Shariah- } \\
\text { compliant }\end{array}$ & $\begin{array}{c}\text { Muslim } \\
\text { Friendly }\end{array}$ & $\begin{array}{c}\text { Muslim } \\
\text { Friendly }\end{array}$ & $\begin{array}{c}\text { Shariah- } \\
\text { compliant }\end{array}$ \\
& $\begin{array}{l}\text { 1-7 } \\
\text { Rating }\end{array}$ & 1-7 Crescent & Bronze, \\
& Silver, & Medium, \\
& & & Gold \& & High \\
& Platinum & \\
\hline $\begin{array}{l}\text { Level of } \\
\text { Shariah } \\
\text { compliance }\end{array}$ & Average & Average & Average & High \\
\hline Complexity & Low & Low & Low & High \\
\hline Practicality & Average & High & High & Low \\
\hline Popularity & Average & High & High & Low \\
\hline
\end{tabular}

According to Idris and Abd-Rahman (2017), it is not easy to market Islamic hotel especially with the rise of Islamophobia which makes it more difficult for Shariah-compliant hotels to compete in the hospitality industry where the market is competitive. Furthermore, in order to be positioned as Islamic hotels, it is important to embrace Islamic values and have a Muslim hospitality ambience, Islamic human resource and Islamic financial system that are based on Islamic principles (Razalli, Ismail \& Yaacob, 2015; Samori \& Rahman, 2013). Hotels may need to reengineer their existing business operation and business process to ensure it adheres to Islamic principles (Razalli et al., 2012). Some of the hotel operators are having difficulties to abide by the Islamic principles 
due to the concern on non-Muslim guests' perceptions (Razalli et al., 2015; Md-Salleh, Abd-Hamid, Hashim\&Omain, 2014).

Although the adoption of Islamic hotel concept is challenging, it is beneficial for Malaysian hotel operators to consider adopting IQS. This is because Islamic tourism and hospitality has tapped into a large business, and Malaysia has the competitive advantage to attract Muslim travelers in Malaysia and all around the world (MasterCard \&CrescentRating, 2016;Razalli et al., 2015; Zainol, Ahmad \& Shariff, 2016). The high adoption of CrescentRating Standard and Salam Certification worldwide confirms the significance of Islamic hotel concept. In Malaysia, among the hotels that have adopted CrescentRating Standard are: Grand Blue Wave Hotel Shah Alam (7 crescent), PNB Perdana Hotel and Suites on the Park ( 7 crescent), Hotel Perdana Kota Bharu (6 crescent), Dorsett Grand Subang (5 crescent), Grand Lexis Port Dickson (5 crescent), The Regency Hotel Kuala Lumpur (5 crescent), Swiss Hotel Heritage Boutique, Melaka (4 crescent) and Hard Rock Hotel Penang ( 3 crescent). Salam Standard is adopted by more than 472 hotels in Malaysia (Tripfez, 2019).IQS was launched two years earlier than Salam Standard. However, only De Palma Hotels and The Grand Blue Wave Hotel have adopted IQS in Malaysia.

\section{Method}

This study used questionnaire to examine the intention to adopt IQS. Attached with the cover page of the questionnaire is a brief description of IQS which covers Islamic hotel characteristics. The questionnaire was adapted from Magdalene, Ramayah and Amin (2015). The variable contains three items which were measured using 5 points Likert's scale ranging from "strongly disagree" to "strongly agree". The three items were: "I intend to adopt IQS in my hotel", "I would adopt IQS if there is any opportunity to do so" and "I would actively seek out for IQS adoption in my company". Three academicians from tourism and hospitality programme and two experts from the industry were consulted to test the instrument's validity. To measure the reliability, Cronbach's alpha coefficient was used and the score was 0. 926.The population was 355 which 
represents the total number of three, four and five-star hotels in Peninsular Malaysia. Data was obtained by distributing questionnaires to all the three, four and five-star hotel managers throughout Peninsular Malaysia. However, only 74 questionnaires were returned and only 72 were usable. Based on Roscoe (1975) the response rate is sufficient given that the number of respondents is more than thirty. Also, the required minimum number of respondents based on the number of variables in the research framework is ten. Finally, the response rate for this study exceeded (although slightly) the minimum requirement which is twenty percent of the population.

\section{Profile of Respondents}

The analysis of respondent's background indicates that 81.9 percent were male and the remaining 18.1 percent were female. Majority of the respondents were Malay (66.7\%), followed by Chinese (19.4\%), Indian $(8.3 \%)$ and other races $(5.6 \%)$. The majority of respondents were Muslims $(68.1 \%)$ and the remaining $(31.9 \%)$ were nonMuslims. In terms of position, most of the respondents were General Managers (59.7\%), and others $(40.3 \%)$ were amongst the Hotel/Resort Manager and members of the Board of Directors of the hotel. More than half $(52.8 \%)$ of the respondents has more than 10 years working experience. In terms of hotel category, 43.1 percent were three-star hotels, 30.6 percent were five-star hotels and 26.4 percent were four-star hotels. The largest group of respondents came from three states; Kuala Lumpur (20.8\%), Selangor (15.3\%) and Kedah (12.5\%).The remaining were from other states in Peninsular Malaysia. Table 6 shows the respondents' profile.

Table 6 
Respondents' Profile

\begin{tabular}{|c|c|c|c|}
\hline $\begin{array}{l}\text { Description of } \\
\text { items }\end{array}$ & Category & Frequency & $\begin{array}{c}\text { Percentage } \\
(\%)\end{array}$ \\
\hline \multirow[t]{2}{*}{ Gender } & Male & 59 & 81.9 \\
\hline & Female & 13 & 18.1 \\
\hline \multirow[t]{4}{*}{ Race } & Chinese & 14 & 19.4 \\
\hline & Indian & 6 & 8.3 \\
\hline & Malay & 48 & 66.7 \\
\hline & Others & 4 & 5.6 \\
\hline \multirow[t]{2}{*}{ Religion } & Muslim & 49 & 68.1 \\
\hline & Non-Muslim & 23 & 31.9 \\
\hline \multirow[t]{2}{*}{ Position } & General Manager & 43 & 59.7 \\
\hline & Others & 29 & 40.3 \\
\hline \multirow[t]{3}{*}{ Star Rating } & 3 star & 31 & 43.1 \\
\hline & 4 star & 19 & 26.4 \\
\hline & 5 star & 22 & 30.6 \\
\hline \multirow{2}{*}{$\begin{array}{l}\text { Length of } \\
\text { Working } \\
\text { Experience }\end{array}$} & $<10$ years & 34 & 47.2 \\
\hline & $>10$ years & 38 & 52.8 \\
\hline \multirow[t]{13}{*}{ State } & Perlis & 1 & 1.4 \\
\hline & Kedah & 9 & 12.5 \\
\hline & Penang & 5 & 6.9 \\
\hline & Perak & 4 & 5.6 \\
\hline & Selangor & 11 & 15.3 \\
\hline & Putrajaya & 1 & 1.4 \\
\hline & Kuala Lumpur & 15 & 20.8 \\
\hline & Melaka & 7 & 9.7 \\
\hline & Negeri Sembilan & 1 & 1.4 \\
\hline & Johor & 6 & 8.3 \\
\hline & Pahang & 3 & 4.2 \\
\hline & Terengganu & 6 & 8.3 \\
\hline & Kelantan & 3 & 4.2 \\
\hline
\end{tabular}




\section{Findings}

\section{Intention to Adopt IQS}

Table 7 indicates the descriptive statistic on the intention to adopt IQS for all 72 respondents. The "mean" score for all three items are higher than 3 but lower than 3.5. Thus, it can be concluded that the hotel operators in Malaysia are neutral about its adoption.

\section{Table 7}

Intention to Adopt IQS

\begin{tabular}{lcc}
\hline Intention to Adopt IQS Items (n=72) & Mean & SD \\
\hline I intend to adopt IQS in my hotel. & 3.14 & 1.12 \\
\hline $\begin{array}{l}\text { I would adopt IQS if there is any opportunity } \\
\text { to do so. }\end{array}$ & 3.40 & 1.08 \\
\hline $\begin{array}{l}\text { I would actively seek out for IQS adoption in } \\
\text { my company. }\end{array}$ & 3.10 & 1.10 \\
\hline
\end{tabular}

Most (45.8\%) of the respondents answered "neutral" for the intention to adopt IQS. The percentage of respondents who were positive (32\%) about the intention to adopt IQS is only slightly higher than those who were negative $(22.2 \%)$ about it. Almost all of the respondents who were positive about the adoption of IQS were Muslim. However, even among the Muslims, the majority were neutral $(40.8 \%)$ about its adoption, and some were negative $(16.3 \%)$ about it. Many hotel owners and operators in Malaysia are nonMuslim and the findings of this study have indicated that only a few non-Muslim $(8.7 \%)$ intends to adopt IQS. The low response rate among the non-Muslim may also indicate a disagreement towards the adoption of IQS and Islamic Hotel concept. Table 8 shows the details of the comparison between Muslim and non-Muslim intention to adopt IQS. 
Table 8

Details of Intention to Adopt IQS

\begin{tabular}{|c|c|c|c|c|c|c|c|c|}
\hline & & & $\begin{array}{l}\text { Strongly } \\
\text { Disagree }\end{array}$ & Disagree & Neutral & Agree & $\begin{array}{c}\text { Strongly } \\
\text { Agree }\end{array}$ & Total \\
\hline \multirow{4}{*}{ Religion } & \multirow[b]{2}{*}{ Muslim } & Count & 2 & 6 & 20 & 11 & 10 & 49 \\
\hline & & $\begin{array}{l}\% \text { within } \\
\text { Religion }\end{array}$ & $4.1 \%$ & $12.2 \%$ & $40.8 \%$ & $22.4 \%$ & $20.4 \%$ & $100.0 \%$ \\
\hline & \multirow[b]{2}{*}{$\begin{array}{l}\text { non- } \\
\text { Muslim }\end{array}$} & Count & 5 & 3 & 13 & 2 & 0 & 23 \\
\hline & & $\begin{array}{l}\% \text { within } \\
\text { Religion }\end{array}$ & $21.7 \%$ & $13.0 \%$ & $56.5 \%$ & $8.7 \%$ & $0.0 \%$ & $100.0 \%$ \\
\hline \multirow{2}{*}{ Total } & & Count & 7 & 9 & 33 & 13 & 10 & 72 \\
\hline & & $\begin{array}{l}\% \text { of } \\
\text { Total }\end{array}$ & $9.7 \%$ & $12.5 \%$ & $45.8 \%$ & $18.1 \%$ & $13.9 \%$ & $100.0 \%$ \\
\hline
\end{tabular}

\section{Difference between Muslim and non-Muslim}

T-test was used to measure the difference between the Muslim and non-Muslim intention to adopt IQS. Specifically, t-test measures the difference between the mean of the two groups. Result from t-test indicates that there is a statistically significant difference $(\mathrm{t}(70)=$ 3.299, Sig. $=0.002)$ between the mean of the Muslim $(\mathrm{M}=3.47$, $\mathrm{SD}=1)$ and non-Muslim $(\mathrm{M}=2.67, \mathrm{SD}=0.876)$ in their intention to adopt IQS. The mean difference between the two was 0.803 , which is small. It is therefore concluded that the Muslim intention to adopt IQS is higher than the non-Muslim. Table 7 shows the result of independent samples t-test analysis on religion and intention to adopt IQS.

Table 7 
Independent samples t-test analysis on religion and intention to adopt IQS

\section{Group Statistics}

\begin{tabular}{cccccc}
\hline & Religion & $\mathrm{N}$ & Mean & Std. Deviation & Std. Error Mean \\
\hline \multirow{2}{*}{ mean_bi } & Muslim & 49 & 3.47 & 1.000 & .143 \\
& non-Muslim & 23 & 2.67 & .876 & .183 \\
\hline
\end{tabular}

Independent Samples Test

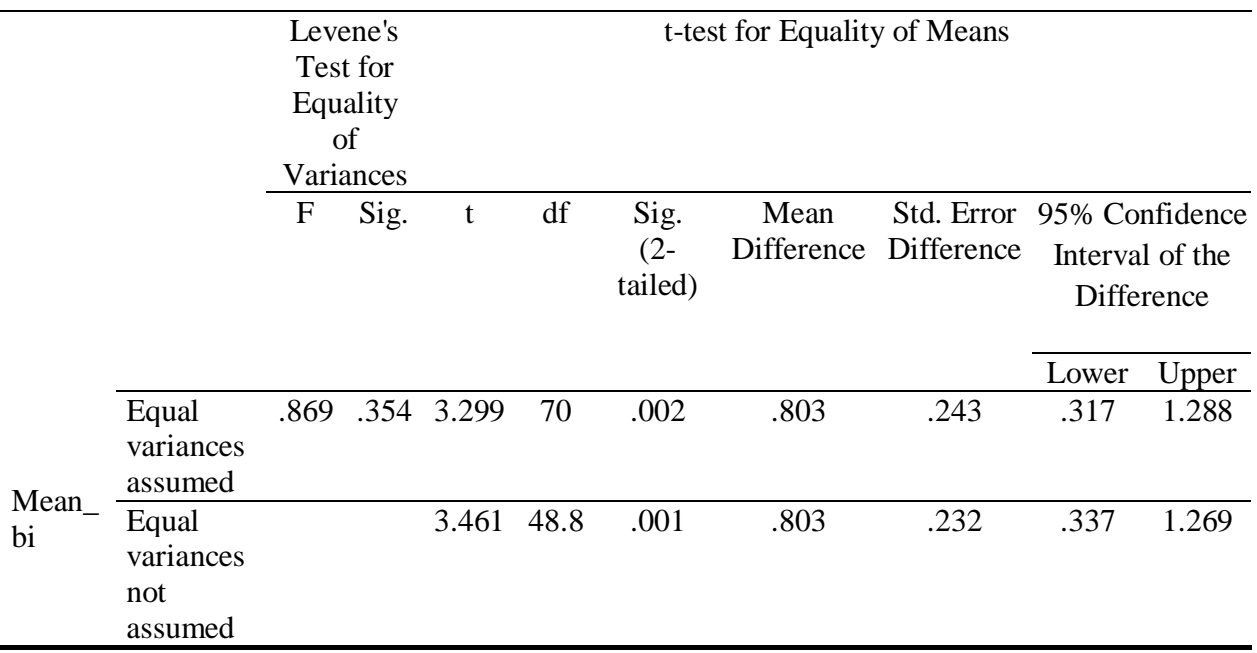

\section{Discussion}

The finding of this study reveals that many hotel operators are reluctant to adopt IQS especially the non-Muslim. Secondary data that is obtained from past studies, IQS, CrescentRating, and Salam Standard website revealed that it is easier for hotel operators to adopt Muslim-friendly certification such as Salam Standard compared to IQS

Hotel operators are reluctant to adopt IQS especially the nonMuslim

This finding is consistent with Zainol, et al. (2016), whose qualitative study explained the barriers of implementing Shariah- 
compliant hotels. Among the barriers listed were negative perception of Shariah-compliant operations among non-Muslims and operational issues of Shariah-compliance concepts. Similar issues were highlighted in previous studies by (Razalli et al., 2012; Rosenberg \& Choufany, 2009; Samori \& Rahman, 2013). Examples of the negative perception among the non-Muslims are Islamophobia or prejudice against Islam, the perception that Shariah-compliant is very Islamic, and Islam is rather restrictive (Idris \& Abd-Rahman, 2017; Zainol, et al., 2016).Furthermore, the restriction from selling non-halal food and beverages especially liquor will reduce the hotel's profit and dissatisfy the non-Muslim guests (Henderson, 2010; Zainol, et al., 2016). In simpler words, hotel operators are afraid that the adoption of Islamic hotel concept will result in losing non-Muslim customers and reduced profit. The operational issue regarding the difficulty in obtaining Halal certificate by JAKIM is widely discussed in Md-Salleh et al. (2014), and the authors mentioned that hotel operators requested for the Halal certification process to be simplified. Other operational issues are the segregation of gender and those with families, and the requirement for spacious room that may complicate capacity planning and incur extra costs (Samori, 2013).

To solve the issue of Islamophobia, Idris and Abd-Rahman (2017) suggests hotel operators to change their marketing strategies by using creative and innovative ideas which may help in creating public awareness towards their brands and service offered. With the use of Muslim-friendly instead of Shariah-compliant term and attractive marketing communication that portrays efficiency, professionalism and value to the brands, hotels may gain competitive advantage and be able to compete and succeed in the market. However, the operational issues of Islamic hotel concept which requires hotel operators to reengineer their physical facilities, business operation and business process remain unresolved.

Hotels are profit oriented business that aims to maximize profit by attracting and satisfying as many travelers regardless of their religion, and it is crucial for the hotels to conform to its diverse customer needs (Samori, 2013). While the Muslim requires halal restaurant, the non-Muslim prefers non-halal food and beverage such as liquor. Therefore, businesses would rather cater to the basic 
faith-based needs of the Muslim guests when traveling, and not to be mistaken for Hajj and Umrah pilgrimage needs. Different from other types of travelling purposes, during Hajj and Umrah, Muslims travel to Mekah and Madinah mainly due to religious needs. Thus, most of the time and activities are concentrated on the devotion to Allah. This is not the situation when traveling for other reasons. As mentioned by Jafari and Scott (2014), Muslim traveler's choice of destination may be influenced by their main purpose of travel, which could be religious or non-religious based. The travel to Mekah for Hajj and Umrah is religious based, whereas the travel to Malaysia is for non-religious purposes such as business and leisure. However, despite the purpose of travel, it remains crucial for the Muslims to pray, consume halal food and beverage, abide to the Muslims dress code, and fast in the month of Ramadhan.

To increase the adoption of Muslim-friendly branding and certification among hotel operators, it is crucial for the certification body to identify what the Muslim guests really need when traveling, and to what extent the hotel operators are willing to fulfill their needs. Based on Yusof and Ramli (2019) quantitative study, it is discovered that the Muslim tourists placed their highest expectations on the availability of halal food with halal identification, and the necessities for prayer such as prayer rooms, information on prayer times and prayer mat. Using a five-point Likert scale with scale 1 for being "not at all important" to 5 being "very important" the mean score for the availability of halal food with halal identification and the necessities for prayer is between 4 to 4.17 which indicates high importance. The mean score for the segregation of genders and those with family, and the provision of the Holy Quran was also high but it was below 4.0. This means a hotel with Gold Salam Standard and four or five Star Rating that also provides Holy Quran upon request and indoor pool for the ladies, might be able to attract Muslim customers while not having to risk losing their non-Muslim customers. 


\section{Muslim-friendly standard is widely accepted but not Shariah- compliant certification}

Salam Standard has been accepted by many hotel operators worldwide, regardless of their level of service ranging from budget to luxurious hotels (Salam Standard, 2019). Prior to setting its criteria, Salam Standard identified the important services and amenities that the Muslim travelers need when traveling (Salam Standard, 2019). With Salam Standard Certification, hotels can be classified as Gold when they offer halal certified food for breakfast and room service. When the whole premise is alcohol-free, the hotel is certified as Platinum, which is the highest standard. Thus, Salam Standard allows hotels to obtain Gold standard without sacrificing their Star Rating. Conversely, IQS aims to replace the renowned and well established Star Rating. Furthermore, Salam Standard rating scale is the easiest to comply (for the non-Muslim hotel operators) compared to all other standards discussed in this study including IQS. This supports the reason why Salam Standard uses Muslimfriendly instead of Shariah-compliant label.

There is a difference between being Muslim-friendly and Shariah-compliant (CrescentRating Staff Writers, 2016). Therefore, it is important to make it clear because it will affect the hotel's branding. In CrescentRating glossary of terms, Muslim-friendly facility or service is defined as the service or facility that takes into account some faith-based needs of Muslim travelers (CrescentRating Staff Writers, 2016). Based on CrescentRating glossary of terms, Halal friendly may also convey the same meaning as Muslim-friendly but the term Muslim-friendly is more appropriate. On the other hand, Shariah-compliant service or facility is defined as the service or facility that caters to all the key needs of Muslim travelers, and strictly adheres to many of Islamic requirements and principles such as company governance and operations (Razalli et al., 2012; CrescentRating Staff Writers, 2016). Based on the information gained from the four (IQS, CrescentRating, Salam Standard and SIHAT) certification criteria, this study finds that SIHAT is clearly meant for hotels that intend to practice Islamic hospitality which is Shariah-compliant. IQS criteria indicate that it is skewed towards Islamic Hotel and Shariah- 
compliant while CrescentRating and Salam Standard are Muslimfriendly. The difference between IQS and CrescentRating is exemplified in the certification of the Grand Blue Wave Hotel, Shah Alam. The hotel was certified with only three Crescent by IQS but seven Crescent by CrescentRating (Blue Wave Hotels, 2019). However, with seven Crescent by CrescentRating, hotels have the potential to attract the "religious" and even "very religious" Muslims.

\section{Religiosity Level Varies}

Religiosity level varies among the Muslim travelers, and matching hotel services with the target market is the utmost priority. Yusof and Ramli (2019) requested their respondents to rank their religiosity level. Out of 462 respondents, $17.9 \%$ are "very religious", 50.9\% are "religious", 25.3\% are "mildly religious" and lastly $5.8 \%$ of the Muslim travellers admitted that they are "secular" Muslims. While this implies that many of the Muslim travellers are religious, it may also justify the difference in the intention to adopt IQS among the Muslim respondents in this study. On the other hand, certification bodies such as CrescentRating can cater to the needs of non-Muslim and Muslims of various religiosity levels. While hotels which aim to attract Muslim customers but do not want to risk losing non-Muslim customers can opt for five Crescent or below, hotels which aim to specialize in catering to the Muslims needs can opt for six and seven Crescent. Due to the specialization, it seems appropriate for the hotels to market themselves as Islamic Hotel.

This study contributes to the literature on Shariah-compliant and Muslim-friendly hotel by giving the statistic of hotels that intend to adopt IQS, thus fulfilling the technical requirements of Islamic hotel concept in Peninsular Malaysia. This study provides knowledge about Islamic hotel concept, IQS and other assessment tools that are related to Islamic hotel concept, and the intention to adopt IQS among Muslim and non-Muslim hotel operators. Indirectly, the intention to adopt IQS may reflect the intention to adopt Islamic hotel concept. Therefore, the findings of this study can be used to improve IQS and its adoption, and promote the growth of Islamic hotels in Malaysia in terms of its number and direction. 
This study is relevant to civilization as it includes discussions on how the assessment tools related to Islamic hotel concept can be improved in order to promote the growth of Islamic hotels in a profit oriented business environment with multi religious stakeholders. The non-Muslim, especially the westerners have the perception that Islam is a set of long-established cultural and traditional beliefs and practices which are odd (Bakour, 2018). In this paper, the perspective of the non-Muslim is taken into considerations. This is deemed necessary as many of them are hotel operators, owners and potential guests. Civilization acknowledges the need for promoting peace and making the planet a livable place for all because despite our diversity, we have the same needs (Chowdury, 2017). Peace can be instilled through positive interaction and cooperative relationship among the Muslim and non-Muslim (Bakour, 2018). Therefore, the assessment tools related to Islamic hotel concept that is acceptable by the Muslim and non-Muslim promotes peace as it allows for positive interaction and cooperative relationship among various stakeholders regardless of their faith.

\section{Conclusion}

Given that the response rate of this study is very low yet acceptable, it is recommended that future studies conduct a longitudinal quantitative study to assess the performance of hotels that adopt the Islamic hotel concept. This can help identify whether Malaysia already has sufficient number of Islamic hotels to cater to the global Muslim travel market, and how the Islamic hotels can improve their performance in terms of profit and service delivery. Future studies can also explore whether Muslim-friendly service sufficiently satisfies the needs of the Muslim travelers, especially in terms of faith-based expectations.

\section{Acknowledgement}

This research is funded by Ghazali Shafie Graduate School of Government, Universiti Utara Malaysia through Postgraduate Research Incentive Grant. 


\section{References}

Ahmat, N.C., Ridzuan, A.H.A., Din, N., Zainol, N. \& Razali, M.A. (2015). Shariah-compliant hotel: The concept and practices. Journal of Tourism, Hospitality \& Culinary Arts, 7 (2), 5266.

Bakour, B. (2018). Islam and the west: From clash to dialogue. KATHA, 14, 1-31.

British Muslim Magazine (2015). World's first hotel standard for Muslim travelers launches today. Retrieved from http://www.britishmuslimmagazine.com/2015/10/22/worlds-first-hotel-standard-formuslim-travellers-launches-today/

Channel Muslim Media News (2013). Islamic Quality Standard for hotel is officially launched. Retrieved from http://cmmnews.blogspot.com/2013/06/iqs-islamic-quality-standardfor-hotel.html

Chowdury, A.K. (2017). Culture of peace: Agenda for a new global civilization. Retrieved from http://ihan.org/ihan/culture-ofpeace-agenda-for-a-new-global-civilization/

CrescentRating.(2019). The world's leading authority on halal travel.Retrieved from https://www.crescentrating.com/ratingaccreditations/hotels.html

CrescentRating Staff Writers. (2016). Defining what is halal travel or Muslim-friendly tourism. Retrieved from https://www.crescentrating.com/magazine/muslimtravel/3852/defining-what-is-halal-travel-or-muslimfriendly-tourism.html

Grand Blue Wave Hotel. (2019). Grand Blue Wave Shah Alam. Retrieved from http://www.bluewavehotels.com/ 
Henderson, J. C. (2010). Sharia-compliant Hotels. Tourism and Hospitality Research, 10(3), 246-254.

Idris, J. \& Abd-Rahman, S.S. (2017). Aida Model, Social Media Marketing and Decision to Patronize Muslim Friendly Hotel. Journal of Management \& Muamalah, 7(2), 3-15.

Islamic Tourism Centre. (2018). Tourism Contributed RM81B to Nation's Coffers. Putrajaya: Ministry ofTourism and Culture.

Jafari, J., \& Scott, N. (2014). Muslim world and its tourisms. Annals of Tourism Research, 44, 1-9.

Magdalene C.H. A., Ramayah, T.,\& Amin, H. (2015). A theory of planned behavior perspective on hiring Malaysians with disabilities.Equality, Diversity and Inclusion: An International Journal, 34(3), 186 - 200.

Malaysian Association of Hotel Owners. (2019). Malaysian Association of Hotel Owners members. Retrieved fromhttp://www.maho.org.my/members.html\#

Mastercard \& CrescentRating. (2018). MasterCard-CrescentRating Global Muslim Travel Index 2018. Singapore: CrescentRating Pte. Ltd.

Mastercard \& CrescentRating. (2016). MasterCard-CrescentRating Global Muslim Travel Index 2016. Singapore: CrescentRating Pte. Ltd.

Md-Salleh, N.Z., Abd-Hamid, A.B., Hashim, N.H. \& Omain, S.Z. (2014). The Practice of Shariah-compliant Hotel in Malaysia. International Journal of Trade, Economics and Finance, 5(1), 26-30. 
Othman, N.A. \& Othman, S. (2013). Islamic Quality Standard for Hotels. Kuala Lumpur, Malaysia: Universal Crescent Standard Centre.

Othman, S. (2013). IQS Islamic Quality Standard for Hotel was Officially Launched. Universal Crescent Standard Centre. Retrievedfrom http://universalcrescentstandardcenter.blogspot.com/

Owler (2019). CrescentRating's competitors, revenue, number of employees, funding and acquisitions. Retrieved from https://www.owler.com/company/crescentrating

Pew Research Center. (2011). The Future of the Global Muslim Population: Projections for 2010-2030. Pew Research Center's Forum on Religion \& Public Life.

Razalli, M.R., Abdullah, S. \& Hassan, M.G. (2012). Developing a Model for Islamic Hotels: Evaluating Opportunities and Challenges. In International Proceedings of Economics Development \& Research 42 (pp. 91-95). Jeju Island, South Korea.

Razalli, M.R., Ismail, R.M. \& Yaacob, N.A. (2015). SIHAT: an assessment tool for Shariah-complianthotel operations. International J of Islamic Marketing and Branding, l(1), 5568.

Roscoe, J. T. (1975). Fundamental research statistics for the behavioral sciences. New York: Holt, Rinehart and Winston, Inc.

Rosenberg, P., \& Choufany, H.M. (2009). Spiritual Lodging - the Shariah-compliant Hotel Concept. HVS Global Hospitality Services, pp. 1-7, Dubai.

Salam Standard. (2019). Salam Standard certification. Retrieved fromhttps://www.salamstandard.org/salam-standardcertification.html 
Samori, Z. (2013). Towards the formation of Shariah-compliant Hotels in Malaysia: An exploratory study on its opportunities and challenges. The 2013 West East Institute International Academic Conference Proceedings, Istanbul, Turkey (pp. 108-124).

Samori, Z. \& Rahman, F.A. (2013). Establishing Shariah-compliant Hotels in Malaysia: Identifying Opportunities, Exploring Challenges. West East Journal of Social Science, 2(2), 95108.

Thomson Reuters. (2018). The Global Islamic Economy Report 2017/18. New York: Thomson Reuters.

Travel Weekly Asia. (2017). Salam Standard adds a premium classification scheme. Retrieved from http://www.travelweekly-asia.com/Travel-News/HotelNews/Salam-Standard-adds-a-premium-classificationscheme

Tripfez. (2019). Book Muslim-friendly hotel online. Retrieved from https://www.tripfez.com/

Yusof, N.S. \& Ramli, K.I. (2019). International Muslim travellers' expectation towards Islamic hospitality services in Malaysia. Paper Presented at Symposium on Islamic Tourism, Kuala Terengganu, Malaysia (SIT 2019).

Zainol, N.A., Ahmad, R. \& Shariff, N. (2016). Investigating the barriers and success factors in implementing Shariahcompliant hotel operations. The Social Sciences, 11(6), 71637167. 